\title{
The Crisis of Collectivisation: Socialist Development and the Peasantry
}

\section{Mark Selden}

\section{Introduction*}

At the centre of the 1970 and 1980 eruptions of strike activity culminating in an independent workers' movement and the formation of Solidarnosc in Poland was widespread resentment over the acute shortage and rocketing prices of food. The Polish case well exemplifies aspects of the long term systemic crisis of agrarian development which socialist states have confronted and continue to confront. The Soviet Union, China, Yugoslavia and Poland, all substantial food exporters prior to the revolution, became food importers and, in the Soviet and Chinese cases, two of the world's largest importers. In recent years, moreover, each has embarked on a desperate search for viable agrarian institutions, incentive practices and marketing relationships. In the Soviet Union the kolkhoz (collective farm) has declined in importance $v i s-\grave{a}$-vis both the sovkhoz (state farm) and an expanded private sector; Yugoslavia and Poland years ago acknowledged the failure of collectivisation and restored private agriculture to a position of dominance, within a system of restrictive marketing and purchase practices. China, which appeared until recently to be the most successful in addressing rural problems, has since 1978 introduced a wide range of new incentive, managerial and marketing systems which some see as the prelude to the abandonment of collective agriculture, and which unquestionably mark the most thoroughgoing reforms since the formation of the communes.

Viewed in global perspective, sustained and growing food imports by socialist states to combat food shortages provide dramatic signs of weakness and incorporation in the capitalist world economy from a position of vulnerability. Yet the issues of agriculture cut far deeper to the very heart of socialist development. This article argues that the unresolved agrarian question constitutes perhaps the central dilemma of the political economy of the transition.

With the proliferation of socialist states following World War II as a result of the expansion of Soviet

*This essay develops themes explored in detail with respect to Chinese cooperative experience in my article 'Cooperation and conflict: cooperative and collective formation in China's countryside', in Mark Selden and Victor Lippit, eds, The Transition to Socialism in China (M. E. Sharpe: Armonk, 1982), and with respect to Soviet, Yugoslav and Chinese practice in 'Imposed collectivisation and the crisis of agrarian development in the socialist states', in Albert Bergesen, ed, Crises in the World-System, vol 6, Political Economy of the World-System Annuals, forthcoming (Beverley Hills, Sage). military power in much of Eastern Europe, and with autonomously generated socialist states in Yugoslavia, China, Vietnam and Korea, the Soviet state vigorously pressed collectivisation as the model for universal implementation, the path for agrarian development and a centrepiece for the class and accumulation strategies which were to underlie rapid industrialisation. In the late 1940s and early 1950s each new socialist state, with certain interesting variations, in turn followed the sequence of land revolutionimposed collectivisation. Three decades later, despite widespread criticism of the Stalinist agrarian strategy, collectivisation remains widely regarded as the central feature of socialist rural development. And, for all the human costs imposed and the setbacks dealt to agrarian development, Soviet style collectivisation is still widely viewed as essential to Soviet achievements of high accumulation and rapid industrialisation.

This article addresses two issues:

- the origins of cooperative and collective approaches to the 'agrarian question' in Marxist and Leninist thought and early Soviet practice;

- the formative experience of the Soviet Union culminating in 'the great turn' in the years $1928-33$ as the socialist model for agrarian development, and its consequences for Soviet socialism.

Its goal is to rediscover the most promising elements of theory and praxis toward the creation of a socialist agrarian strategy, and to explore the problems and limits of previous approaches. Its premise is that the agrarian question continues to bedevil all socialist societies committed to the full development of the productive forces and to the flowering of socially rooted cooperative institutions.

\section{The 'Agrarian Question': from Marx to Engels to Lenin}

If the writings and politics of the mature Marx reflect a preoccupation with the proletariat and capitalist development, he also wrote extensively on important aspects of what came to be called the agrarian question' [Draper 1978:317-452].

In an important passage in the section on 'So-called primitive accumulation' in Capital I, Marx summed up the shared limitations of pre-capitalist forms of small-scale peasant agriculture and artisanal industry: 
this mode of production presupposes the fragmentation of holdings, and the dispersal of the other means of production. As it excludes the concentration of these means of production, so it also excludes co-operation, division of labour within each separate process of production, the social control and regulation of the forces of society.

[Marx 1867:927-8]

Marx assumed that capitalist development on a world scale would sweep away all vestiges of such a fragmented 'mode of production' [Marx 1867:928]. Quite incorrectly, both because the household farm has shown extraordinary vigour and resilience under capitalism and because it has been left to socialist revolution everywhere to confront its living legacy in myriad forms of peasant agriculture.

While Marx perceived in the small-scale, fragmented pattern of peasant agriculture a barrier to cooperative production, the division of labour, and the development of the productive forces, he did not rely on the objective workings of capital and the market to solve the agrarian question. We find in Marx the origins of the concept of the worker-peasant alliance as the bulwark of proletarian revolution. While viewing the rural proletariat as the most important ally in the countryside, Marx insisted that it was possible and necessary to win over to the revolutionary camp at least a portion of the peasantry. But how? While Marx, as a revolutionary, never unequivocally ruled out land redistributive strategies, his approach to the agrarian question centred on the eventual elimination of private land ownership and the socialisation of agricultural production. This perspective was mediated by a clear awareness of the necessity for revolutionaries to develop an agrarian strategy based solidly on the protection of peasant interests and winning active peasant support. Marx's notes on a polemic of Bakunin make the point well. The proletariat, he insisted, must:

take measures whereby the peasant sees his situation immediately improved and which therefore win him over to the revolution - measures however, which in embryo facilitate the transition from private property in land to collective property, so that the peasant comes to it by himself, for economic reasons.

[Draper 1978:409]

The convoluted quality of this formulation suggests one of the most difficult challenges which socialist revolutionaries would everywhere confront in the twentieth century.

In his final work addressed to the peasant question, Friedrich Engels envisaged that large landed estates would be 'organised into cooperatives ... under the control of the community'. 'The example of these agricultural cooperatives' he held, 'would convince also the last of the still resistant small-holding peasants, and surely also many big peasants, of the advantages of cooperative, large-scale production'. The peasantry, would be won to the virtues of largescale cooperative agriculture by the power of example, not, as all agreed, by coercion.

Lenin and the Bolsheviks came to power in 1917, sharing many of the perspectives on the agrarian question of Marx and Engels enumerated above. In 1907 , to clear the land 'of all medieval lumber', Lenin had urged 'the nationalisation of the land, the abolition of the private ownership of land, and transfer of all the land to the state, which will mark a complete break with feudal relations in the countryside' [Lenin 1907:169]. In his April 1917 Theses and then in the Bolshevik Party's resolution on the agrarian question, however, Lenin combined the principle of land nationalisation with 'the immediate transfer of all lands to the peasantry organised in Soviets of Peasants' Deputies, or in other organs of local self-government elected in a really democratic way and entirely independent of the landlords and officials'. In short, the right to cultivation of the nationalised land is vested in local democratic institutions' [Lenin 1917:190]. However, it is by no means clear whether the power of 'organs of local self-government' implied a shift to cooperative forms of agricultural production or whether it simply marked the Bolshevik acceptance of household based agricultural production. The attempt to win the support of the peasantry, coupled with the absence of any significant Bolshevik presence in the rural areas, resulted in the abandonment of nationalisation in favour of the programme long advocated by the Social Revolutionaries in which land-hungry peasants were encouraged to seize and subdivide the large estates into individually cultivated holdings [Hussain and Tribe 1981:80-99]. Land parcellisation and redistribution thus entered the Bolshevik arsenal as a weapon which stood in direct conflict with the principal strat egies advanced earlier by Marx, Engels and Lenin himself; such land reform was carried out in virtually all subsequent socialist revolutions with the exception of Cuba.

It is customary to pass quickly over the policies of the War Communism period (1917-20) as a set of exceptional emergency measures whose excesses were rapidly corrected by the New Economic Policy (NEP). But as the Hungarian economist Laszlo Szamuely has convincingly demonstrated, regardless of the impact of war, the policies of this period - the creation of a centralised subsistence economy, abolition of money and commodity relations, heavy reliance on compulsory labour mobilisation and egalitarian distribution - embodied shared concepts of the transition period held by all leading Bolsheviks from Bukharin 
and Trotsky to Preobrazhensky and Lenin [Szamuely 1974:10-44]. ${ }^{1}$

If the Bolsheviks entered 1917 with at best weak linkages to the peasant majority, under War Communism the Soviet state and the peasantry clashed head on as a result of state imposed grain sales and outright confiscation. When the proposal to exchange commodities for grain produced insufficient supplies to feed the cities, a decree of 9 May 1918 set compulsory sales quotas for peasants and called on urban workers and poor peasants to confiscate 'surplus' grain. The free market in grain was thus legally abolished, though it continued to exist illicitly [Szamuely 1977:16-17]. These were emergency measures taken in response to the wartime crisis, but at another level they were consistent with certain characteristic Bolshevik approaches to the peasantry.

The failure of compulsion to solve the supply crisis led Lenin to conceptualise the course which eventually came to be dubbed the New Economic Policy. In 1919 Lenin analysed the problem of the transformation of the peasantry as a complex and long process. It is necessary, he wrote,

to abolish the difference between working-man and peasant, to make them all workers. This cannot be done all at once. This task is incomparably more difficult and will of necessity be a protracted one. It is not a problem that can be solved by overthrowing a class. It can be solved only by the organisational reconstruction of the whole social economy, by a transition from individual, disunited, petty commodity production to large scale social production. This transition must by necessity be extremely protracted. It may only be delayed and complicated by hasty and incautious administrative and legislative measures. It can be accelerated only by affording such assistance to the peasant as will enable him immensely to improve his whole agricultural technique, to reform it radically.

[Lenin 1919:318]

In 1923, in the final year of his life, Lenin began to focus on the importance of cooperatives as the centrepieces of state policy during the transition to socialism in the countryside. But he had in mind not the peasant communes (kommuna) which had flowered briefly with some official support in 1918-19 and which organised production and consumption on a basis of equal sharing. Rather, with the state guaranteeing private ownership and cultivation of land in the NEP, and with the Bolsheviks still lacking a firm base in the countryside, Lenin's call for cooperatives focused on trading cooperatives. With this as a first step toward winning peasant support for protosocialist institutions, and after the technological

'Szamuely traces the origins of the War Communism approach to earlier social democratic theoreticians, including Kautsky. revolution (tractors, electricity, chemical fertiliser) made possible an appropriate material basis, Lenin held, collectivisation of agriculture would then become feasible [Lenin 1923:708]. Both material and political preparations for collectivised agriculture would require painstaking efforts but it was hoped that the peasant could be led to socialism by the power of cooperative example, strengthened by the technicalmaterial support of the state. State policies would ensure that the peasantry would gradually come to recognise that large-scale collective agriculture was in its direct material interest, and the urban-rural gap could gradually be narrowed.

The core of NEP practice was not gradual cooperation but the attempt to win peasant support and to obtain much needed grain through the revival of market mechanisms - including free markets and the payment of higher state purchasing prices designed to stimulate increased production and sales. Yet as the 1920s advanced, despite economic recovery (and in part because of it), conflict between the peasantry and the Soviet state over the grain issue deepened, calling into question fundamental principles of NEP and the future of Soviet socialism.

\section{The Great Turn: Imposed Collectivisation as 'Socialist Agrarian Policy'}

Imposed collectivisation, the centrepiece of Soviet agrarian policy since 1929, indeed of the entire political economy constructed under Stalin's leadership, was inflicted by the Soviet state over the opposition of all rural classes, and at immense human and material cost for the long-term prospects of the countryside and agrarian development. This form of collectivisation constituted the negation of the soundest elements of the Marxist and Leninist visions of socialist transformation, and particularly of the processes of gradual, voluntary cooperation which Lenin had envisaged, though done little to implement.

This was by far the most ambitious institutional restructuring attempted in the entire history of the Soviet Union and of other socialist countries which have implemented collectivisation. In no other sector have the relations of production, including ownership, labour process and remuneration, been so fundamentally transformed. Yet imposed collectivisation was the product of no articulated strategy on the part of Stalin or others; still less was there advance understanding or agreement within the top Bolshevik leadership, although we note certain significant continuities of approach and political style with the politics of War Communism.

As of 1929, the structural and organisational parameters of collective institutions had been neither 
designed nor tested, though some useful experience with small-scale cooperation had been gained. In the late $1920 \mathrm{~s}, 36$ research institutes were studying problems of industrialisation; not one was engaged in research on agriculture [Lewin 1968:353].

Because of its immense influence on all subsequent socialist attempts to forge an agrarian policy, we will attempt to reconstruct the origins of the Soviet drive to collectivisation which, once underway, produced the 'Great Turn', and to assess the consequences of collectivisation within the larger parameters of Soviet socialist development.

What process led the Soviet Union from the policy constellation associated with NEP to instant imposed collectivisation and the mass deportation of the 'kulaks'? The answers to this question lie embedded in the crisis of accumulation and marketed grain which confronted the Soviet state in the mid-1920s.

Without minimising the extraordinary economic and political challenges which the first socialist state confronted in the $1920 \mathrm{~s}$ as initial hopes for the universal spread of revolution and support for its industrialising plans were dashed, it must be emphasized that the heart of the problem of the grain shortages of the late 1920 s lay in state pricing and marketing policies which wreaked havoc with the peasantry. By the mid-1920s, policies associated with the NEP had succeeded in stimulating the agrarian economy which was then organised on a household basis: by 1926 agriculture had regained, and livestock exceeded, pre-war production levels - though grain production was still just 92 per cent of the pre-war high [Lewin 1968:172; Davies 1980a:3]. ${ }^{2}$ The central problem, however, lay with marketed grain, which in 1926 was approximately $10 \mathrm{mn}$ tons compared with $18.8 \mathrm{mn}$ tons in 1913 - the record year. In 1926, the state slashed purchasing prices for grain by $20-25$ per cent, attacked peasant private trade and cut back sharply on the provision of industrial goods to the rural areas. The inevitable results of this onslaught against NEP and the peasantry included peasant efforts to shift from grain to the production of other crops; to channel larger quantities of grain toward livestock rather than the market; and to sell the maximum possible in private markets which offered substantially higher prices than those offered by the state [Nove 1971:70-1]. Where Bukharin continued to talk about the need for progress 'at a snail's pace' based on wooing the peasantry, the 1926 policies marked the victory of Preobrazhensky and others who stressed the use of price and sale quota mechanisms to siphon resources from the peasantry as the foundation for primitive socialist accumulation and industriali-

\footnotetext{
${ }^{2} \mathrm{R}$. W. Davies describes the peasant economy in the years $1922-26$ as 'a brilliant success'.
}

sation [Preobrazhensky 1926:30, 84,88; Nove 1965xi-xii].

The critical problem with this strategy was that it acutely aggravated the very difficulty it was designed to solve. By 1928, grain procurements were just half those of the peak pre-war year and the Soviet Union had ceased to be a grain exporter. It was at precisely this moment, as Soviet planners attempted to launch their ambitious first Five Year Plan with its focus on industrialisation and the necessity to secure foreign exchange, that the grain shortage assumed crisis dimensions [Lewin 1968:172].

In 1928 collectivisation was on the lips of no leading Soviet official; the order of the day was the extraction of substantially larger quantities of grain from a reluctant peasantry. Stalin led the procurement drive, personally pinpointing 'kulak sabotage' as the heart of the problem and then imposing coercive approaches to grain extraction which struck at all rural classes [Lewin 1968:214-44; Davies 1980a:56-97]. The military language and methods of the drive recreated the atmosphere of War Communism throughout the countryside.

Was there in fact a 'kulak' problem and, if so, in what did it consist? Policies associated with NEP had made possible (even encouraged) a degree of rural class differentiation, and it is unquestionably true that there are observable tendencies throughout the 1920 s for a small number of middle peasants to become rich peasants while others declined to the ranks of poor and landless peasants. The central fact, however, is that as a result of state extraction and controls on marketing policies, by 1928 no powerful 'kulak' class had emerged. The most important tendency of the preceding years was the strengthening of the ranks of the serednyaks (middle peasants who produced a modest surplus) who, according to Strumilin and the Central Statistical Board, in 1926-27 accounted for 68 per cent of the rural population [Bettelheim 1978:87-8]. Estimates of the 'kulak' population vary between two and five per cent and Kritsman observed that only one per cent of the farms hired more than one labourer. In the agitprop of the grain confiscation drive, the 'kulak' was portrayed as the enemy and target, but the reality was that most of the grain was actually requisitioned from the ranks of the much larger serednyak group [Lewin 1968:69-78]. The small 'kulak' group neither controlled the lion's share of grain surplus nor distinguished themselves in sabotaging state procurement plans. As E. H. Carr aptly observed, "it was no longer true that class analysis determined policy. Policy determined what form of class analysis was appropriate to the given situation' [Carr 1964:99].

In April-May 1929, at the height of the grain crisis, the Soviet Union hastily drafted and launched its first Five 
Year Plan projecting grandiose targets, including a 2.5 fold increase in investment (3.2 times optimal) and annual industrial growth rates of 21.5 per cent $(25.2$ per cent optimal). The goal was an 81.6 per cent rise in national income ( 103 per cent optimal) and, according to the plan, working people would share the benefits: real wages were slated to rise for industrial workers by 58 per cent ( 71 per cent optimal) and for agricultural workers by 30 per cent [Lewin 1968:344-5]. The plan was predicated on the expansion of the sovkhoz and kolkhoz sector to account for 13 per cent of the sown grain acreage and 32 per cent of the nation's marketed grain by 1932 [Lewin 1968:353-4]. The reality proved quite different.

Before turning to that reality, it is worth recalling the outlines of the agrarian strategy being discussed in 1928 and early 1929 . In the short run, the vast majority of the peasantry was to be linked to the state plan not by the immediate transformation of production relations but through contractual relations committing it to the sale of fixed quantities of grain to the state. The state would gradually encourage and support kolkhoz formation over a five-year period to include $4.5 \mathrm{mn}$ households. The concentration of the 120,000 available tractors in the kolkhozes was to provide a demonstration effect of the merits of socialised farming to the peasant majority of private cultivators. The growth of industry, meanwhile, would make possible substantial increases in the production of tractors, agricultural machinery and chemical fertilizer, the material base for an industrialised collective agriculture. As Lewin has observed, 'the question of mass collectivisation affecting the majority of the peasantry was one which had not even arisen ... there was general acceptance of the principle that both large-scale agricultural production and collectivisation could only be introduced gradually, as material

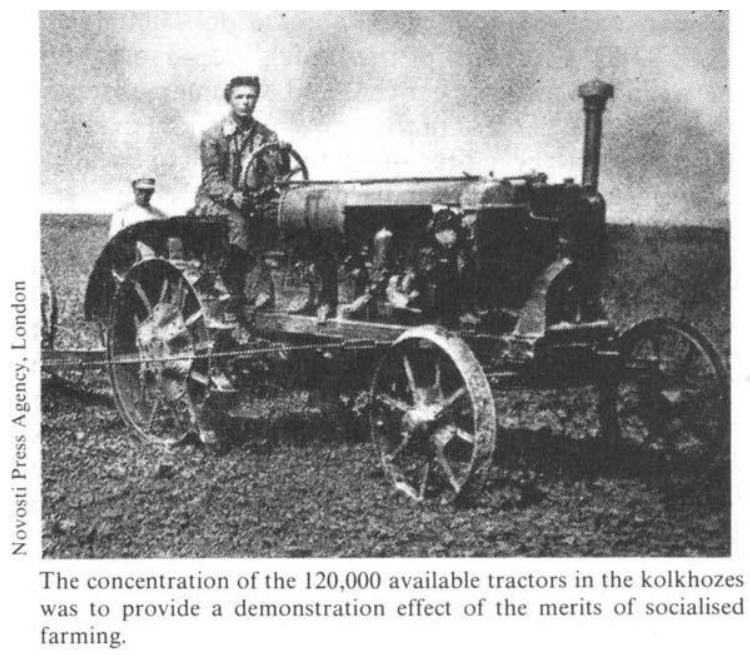

circumstances permitted' [Lewin 1968:355-7]. The experiments with mechanised collectives and the expanded production of the means of mechanisation would provide the experience, the material foundations, and the desire on the part of the majority of peasants voluntarily to join large-scale collectives.

This approach was obliterated in the 'Great Turn' of 1929. The grain procurement drive swiftly turned into an onslaught against the 'kulaks' which in turn gave way to command collectivisation which within a matter of weeks forced millions to give up their land and join collectives whose methods of operation and remuneration remained unknown.

Proclaiming that millions of peasants now favoured collectivisation, Stalin, in 1929 suddenly, without warning or preparation, launched the collectivisation drive demanding the formation of giant multi-village kolkhozes of up to 10,000 hectares at the same time that the call went out to complete the Five Year Plan in four years [Lewin 1968:428, 456]. By June 1929 the euphoria of instant transformation wedded to giantism swept aside earlier discussions of technical and political preconditions. Until that moment the notion that 'millions of sokhi (wooden ploughs) all added together would make an imposing sum' was a matter of ridicule. Now it suddenly became reality [Lewin 1968:460]. Not only land but livestock and household plots were collectivised (that is, confiscated), and a wage system was to provide remuneration [Davies 1980b:172]. The form of collectivisation was thus a virtually complete break with household based agriculture.

In his March 1930 statement, 'Dizzy with Success', Stalin, noting that 50 per cent of the peasants had aiready joined collectives, proclaimed that 'a radical

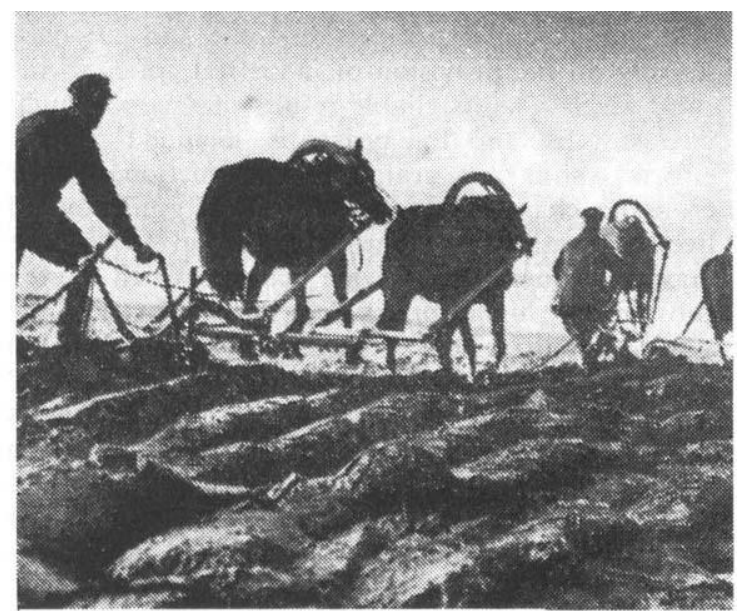

millions of sokhi all added together 
turn of the countryside towards socialism may be considered as already achieved' [Stalin 1930:197]. This signalled the start of a period of consolidation and compromise in which the Soviet leadership retreated from some of the most extreme and unworkable feat ures of the kolkhozes [Stalin 1930:199]. As a result there was a sharp drop in cooperative enrolment how many represented massive defections and how many of those officially enrolled existed in name only, we cannot know. Bet ween 10 March, when 58 per cent of peasant households were reportedly kolkhoz members, and 1 June the number dropped to 23.6 per cent for the entire USSR, that is, more than half the reported members defected, and in some areas like the Central Black region membership plummetted from 82 per cent of the population in March to less than 16 per cent by June [Nove 1971:89]. Several more years would be required to complete collectivisation throughout the Soviet countryside, but the direction and nature of the kolkhozes was essentially set with the series of compromises put in place in 1930. The synthesis which emerged at this time would characterise the central strands of Soviet agriculture, and indeed important elements continue unchanged to the present.

The essential elements of the Soviet agricultural synthesis were these [Millar forthcoming; Davies 1980b; Lewin 1968]:

- state imposed collectivisation. The large kolkhoz became the centrepiece and norm of Soviet agriculture, institutionalising the preference for giantism which finds its parallel in the structure of Soviet industry. In return for the loss of private lands, the kolkhoz member received income not in the form of wages as originally proposed in 1929 but as a share of collective production. This took the form of payment in cash and kind for labour days contributed;

- the private plot and the right to maintain livestock. Initially eliminated during kolkhoz formation, the private sector was quickly restored as a crucial element in the uneasy quid pro quo between the peasant and the state, and between central plan and market. The contribution of collective labour thus became the precondition for access to the private plot and to raising livestock, pigs, etc. Since the 1930s the household has produced a significant portion of Soviet meat, vegetables and fruit, contributed a substantial share of rural income and preserved the household-based structure of rural life;

- the centralised command procurement structure. This provided the regime with the principle channel for ensuring continued supplies of marketed grain, other foods and commercial crops for the cities, industry, and as a source of foreign exchange. State prices and fixed quotas (with above quota bonuses) provided the structure of control which regulated agricultural sales and integrated agriculture within state plans;

- access to private markets. This was the quid pro quo at the heart of marketing arrangements, precisely parallel to and functionally integrated with private plots in the productive sector. Household plots and private markets were essential elements of the compromise erected following collectivisation; the complement ary systems nevertheless existed in uneasy conflict. They survived precisely because of the vital contribution which the private sector made to Soviet consumption and to peasant willingness to participate in the collective;

- machine tractor stations (MTS) serve the collectives. The MTS was the technological link between state and collective, the channel for disseminating tractors, fertiliser and machinery, and an important outlet for extracting the produce of the countryside. In the name of efficiency, the kolkhozes were simultaneously deprived of direct control over advanced technology and firmly lashed through the MTS to the state;

- the plan as a teleological weapon of the state. This characteristic feature was intimately bound up with the 'Great Leap' mentality which surfaced in 1929 and periodically thereafter, the Stalin cult which likewise may be said to have made its real debut in the same year, and the manipulation of class struggle cat egories to justify state compulsion.

As agrarian strategy, the Soviet Union's abrupt coercive collectivisation has had few defenders in recent years. ${ }^{3}$ The combination of the peasant's revenge in the form of the slaughter of close to half the nation's livestock, and subsequent problems of collective organisations and motivation, have contributed to chronic agricultural problems manifest in low productivity and food shortages. Nevertheless, the view remains widespread, particularly among many Third World activists, that whatever the human costs and erròrs associated with collectivisation, whatever the long-range setback to agricultural production and peasant interests, collectivisation was a necessary precondition for the crowning achievement of the Soviet regime. On foundations of collectivisation rose the industrial structure which enabled the Soviet Union to survive the Nazi onslaught in World War II and subsequently to emerge as a major industrial power. For many, the 'Soviet model' consists precisely of rapid industrialisation made possible by accumulation following the collective path.

The Soviet researcher, A. A. Barsov, has effectively cut the ground from under this argument. To be sure,

${ }^{3}$ One positive recent appraisal of the accomplishments of Soviet socialism, including the major directions of the Stalin period, ignores totally the agrarian sector and issues associated with collectivisation to Soviet industrialisation! See Szymanski [1979]. 
Barsov's study sought to refute the 'petty bourgeois falsifiers' who claimed that Soviet industrialisation rested on the exploitation of the peasantry. But working closely with urban-rural and state-collective capital flows for the 1930s he has shown that in the 1930s the state was forced to subsidise agriculture heavily, both directly in the form of subsidies to the MTS and sovkozes, and through changing terms of trade favourable to the countryside. The state did squeeze the countryside of the agricultural surplus, but costly and inefficient Soviet collectivised agriculture actually required substantial state subsidies both in the short and long run [Millar 1970, 1974]. ${ }^{4}$ Far from providing the surplus which fuelled Soviet industrialisation, following collectivisation the net resource flow was to the countryside.

In his study of Socialist Planning, Michael Ellman sums up the Marxist case for collectivised agriculture:

first, it prevents rural exploitation, that is the emergence of a rural proletariat side by side with an agrarian capitalist class. Secondly, it allows the rational use of the available resources. Thirdly, it ensures a rapid growth of the marketed output of agriculture. Fourthly, it provides a large source of accumulation.

[1979:81]

To the above we may add the belief that large-scale cooperative or collective agriculture can both outproduce private agriculture to assure higher and more equal incomes for all rural producers, and can support institutions which vest substantial control over the land and its product in the hands of the immediate producers.

If our analysis is correct, Soviet approaches to collectivisation in the 1930s, approaches which essentially declared war on the peasantry and set back the development of Soviet agriculture, achieved few if any of these goals. Rather collectivisation provided the crucible within which many of the most anachronistic elements of Soviet state socialism took shape, including the antagonistic relationship between the state and the peasantry, the emergence of the cult of personality, and the foreclosure of the development of democratic processes. Collectivisation, moreover, not only set back rural development by decades, but it also may have drained rather than stimulated overall development, including industrialisation.

That alternative vision of a socialist agrarian policy which we found articulated in various ways in the writings of Marx, Engels and Lenin has yet to be seriously tested. In diverse ways socialist states

${ }^{4}$ For a dissenting view emphasizing the contribution of collectivisation to Soviet industrialisation, see Ellman [1975]. continue to search for solutions to the problems generated by imposed collectivisation, with experimentation centred thus far on redefining the relationship between plan and market and among state, collective and private sectors and searching for greater latitude for the market and private sectors. But a variety of other, perhaps more basic, issues remain open. These include the relative merits of cooperative, collective and state ownership and organisational forms from the perspectives of stimulating accumulation and development of the productive forces, building democratic institutions responsive to member needs within the larger context of national planning, and appropriate scale of production at different levels of technology. A fresh consideration of the essential premises of socialist agriculture is long overdue.

\section{References}

Bettelheim, Charles, 1978, Class Struggles in the USSR: Second Period, 1923-1930, Monthly Review Press, New York

Carr, E. H., 1964, A History of Soviet Russia: Socialism in One Country vol $I$, Macmillan, London

Davies, R. W., 1980a, The Socialist Offensive: the Collectivisation of Soviet Agriculture, 1929-30, Harvard University Press, Cambridge, Mass

-1980b, The Soviet Collective Farm, Harvard University Press, Cambridge, Mass

Draper, Hal, 1978, Karl Marx's Theory of Revolution; vol II: the Politics of Social Classes, Monthly Review Press, New York

Ellman, Michael, 1975, 'Did the agricultural surplus provide the resources for the increase in investment in the USSR during the first Five Year Plan?', The Economic Journal, December

-1979, Socialist Planning, Cambridge University Press

Engels, Friederich, 1894, The Peasant Question in France and Germany, vol 3, Progress Publishers, Moscow, 1969-70

Hussain, Athar and Keith Tribe, 1981, Russian Marxism and the Peasantry, 1861-1930, Macmillan, London

Lenin, V. I., 1959, 'The agrarian programme of socialdemocracy in the First Russian Revolution, 1905-7', Alliance of the Working Class and the Peasantry, Foreign Languages Publishing House, Moscow

-1917, 'Resolution of the Seventh (April) All-Russian Conference of the RSDLP (B) on the agrarian question', Alliance of the Working Class and the Peasantry 
-1919, "Economics and politics in the era of the dictatorship of the proletariat', Alliance of the Working Class and Peasantry

-1923, 'On cooperation' in Robert Tucker (ed), The Lenin Anthology, Norton, New York, 1975

Lewin, M., 1968, Russian Peasants and Soviet Power: a Study of Collectivisation, Norton, New York

Marx, Karl, 1867, Capital. A Critique of Political Economy, Vintage, New York, 1977

Millar, James, 1970, 'Soviet rapid development and the agricultural surplus hypothesis', Soviet Studies, July

-1974, 'Mass collectivisation and the contribution of Soviet agriculture during the First Five Year Plan', Slavic Review, December

-forthcoming, 'Bureaucracy and Soviet rural: the city boys and the countryside', in a volume edited by William Parish

Nove, Alec, 1965, 'Introduction' to E. Preobrazhensky, 1926 -1971 , 'The decision to collectivise' in W. A. D. Jackson (ed),
Agrarian Policies and Problems in Communist and Noncommunist Countries, University of Washington Press, Seattle

Preobrazhensky, E., 1926, The New Economics, Oxford University Press, 1965

Stalin, Joseph, 1929a, A year of great change, on the occasion of the twelfth anniversary of the October Revolution'

-1929b, 'Concerning questions of agrarian policy in the USSR'

-1930, 'Dizzy with success' in his Works, vol 12

Szamuely, 1974, First Models of the Socialist Economic System - Principles and Theories, Akademiai Kiado, Budapest

Szymanski, Albert, 1979, Is the Red Flag Flying? The Political Economy of the Soviet Union, Zed Press, London 